\title{
Article \\ Heraldry in the Republic of Macedonia (1991-2019)
}

\author{
Jovan Jonovski (i)
}

check for

updates

Citation: Jonovski, Jovan. 2021.

Heraldry in the Republic of

Macedonia (1991-2019). Genealogy 5:

94. https://doi.org/10.3390/

genealogy5040094

Received: 31 August 2021

Accepted: 20 October 2021

Published: 27 October 2021

Publisher's Note: MDPI stays neutral with regard to jurisdictional claims in published maps and institutional affiliations.

Copyright: (C) 2021 by the author. Licensee MDPI, Basel, Switzerland. This article is an open access article distributed under the terms and conditions of the Creative Commons Attribution (CC BY) license (https:/ / creativecommons.org/licenses/by/ $4.0 /)$.
Macedonian Heraldic Society, 1000 Skopje, North Macedonia; jonovski@gmail.com

\begin{abstract}
Every European country now has some distinctive heraldic conventions and traditions embodied in the designs and artistic representations of the emblems forming part of its national corpus. This paper deals with these matters in the period from independence in 1991 to the recent change of name in 2019. It deals with the successive designs proposed for the emblem of the state itself, some of which conformed to international heraldic conventions closely enough to be called "arms" or "coats of arms", not including the emblem adopted in 2009. Special attention is given to the distinctive conventions created for municipal heraldry, including its novel legal framework, as well as those governing personal heraldry developed in the twenty-first century. The paper examines the evolution of heraldic thought and practice in Macedonia in the three decades in question, especially in the context of the Macedonian Heraldic Society and its journal, The Macedonian Herald, and its Register of Arms and the Civic Heraldic System it created.
\end{abstract}

Keywords: heraldry in Macedonia; Macedonian civic heraldry; Republic of Macedonia

\section{Introduction}

The Republic of Macedonia became independent from the Socialist Federative Republic of Yugoslavia with the Referendum of 8 September 1991. Democratic Federal Macedonia was formed during the first session of the Anti-Fascist Assembly for the National Liberation of Macedonia (ASNOM) on 2 August 1944 (it later became the People's Republic of Macedonia, a federal unit of the Federal People's Republic of Yugoslavia). In 1963, the name was changed to the Socialist Republic of Macedonia and during the struggle for independence in 1991, it dropped "Socialist" from its name. In February of 2019, with the Prespa agreement, in a highly controversial process, the name was changed to the Republic of North Macedonia. This paper discusses the processes prior to the name change, so the correct contemporary name is used.

The situation with heraldry in Macedonia before 1991 is described by Jonovski (Jonovski 2021a). In this paper, we will consider the heraldry in the Republic of Macedonia, understood as the multitude of coat of arms, and the armorial knowledge and art. (Neubecker 1997, p. 10).

\section{State Emblems}

The Independence of the Republic of Macedonia, established by the Referendum of 8 September 1991 happened with the old symbols. The Soviet-style emblem called "The Coat of Arms of the People's Republic of Macedonia" was adopted on 26 July 1946 (Народното 1946). The purely landscape Socialist style composition, with the sun rising behind the central element, a mountain, was created by the artist Vasilije Popović-Cico (Jonovski 2020, p. 30). The following year, the official rendering of this emblem was slightly altered (Figure 1). 


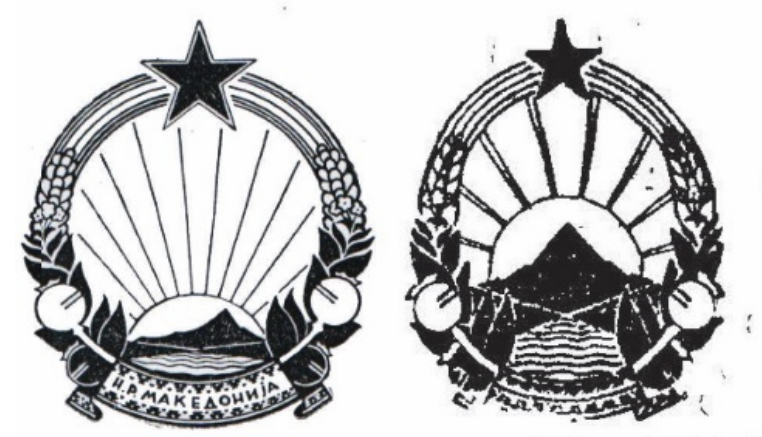

Figure 1. The state emblem of the People's Republic of Macedonia 1946 (left) and 1947-2009 (right).

The Constitution of the Republic of Macedonia, dated 17 November 1991, did not determine the state emblems but provided that they be determined by a law to be adopted by a two-thirds majority vote. According to the Constitutional Law, this should have happened within six months. A Public competition was held for the coat of arms, flag, and anthem. The anthem remained the same, but the Constitutional Commission was not content with arms and flag proposals. The Commission asked the three "winning" designers to submit further proposals including a new design of a golden sun on a red field for the arms and for the flag. The proposal submitted by codename "Feniks 1992" (Kostadin Tanchev Dinkata) was accepted and included in the Commission's official Draft Law on the Coat of Arms submitted by the MPs Tito Petkovski, Zoran Krstevski, and Kiro Popovski on 20 June 1992, as well as a proposal for a flag with the same sun (Figure 2). The draft proposal states:

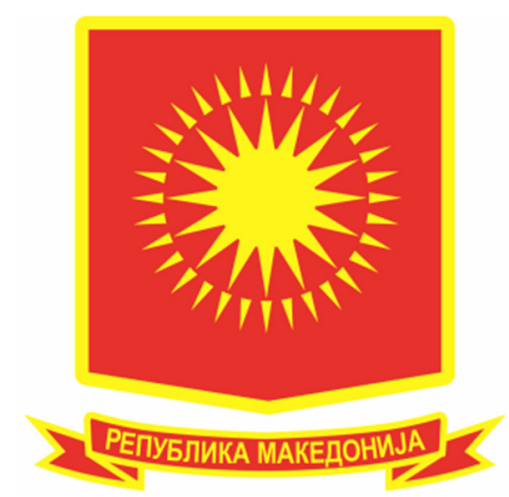

Figure 2. Official proposal of the Constitutional Commission (June 1992).

"The coat of arms of the Republic of Macedonia is a shield with a red field enclosed with a yellow (golden) edge. In the middle of the shield is a yellow (golden) sun. The sun has 16 primary rays that break into 32 rays, 16 of which are at the top of the primary rays, and the other 16 are in the middle between primary rays. Under the shield is a ribbon on which is written 'Република Македонија' (Republika Makedonija)'”'1 ${ }^{\prime}$ The actual blazon is Gules, a sun in splendour with 16 rays, surrounded by circle of 32 secondary rays, Or.

However, in the following month after the 16-rayed sun of the flag was chosen, an agreement was reached for the design of a coat of arms with the same sun (Figure 3). The Proposal of Todor Petrov, on 30 July 1992, is described as follows: 


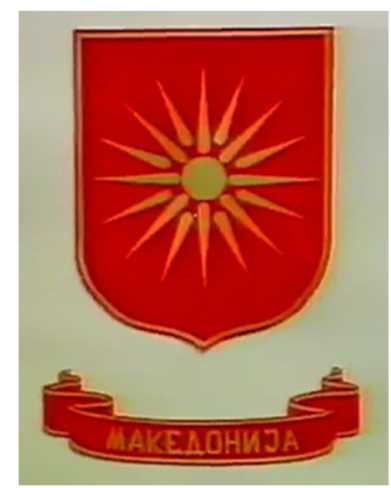

Figure 3. Todor Petrov's proposal accepted by the Commission (July 1992).

"The coat of arms of the Republic of Macedonia is a quadrilateral shield with a red field enclosed with a golden-yellow edge. In the middle of the shield is a golden-yellow sun with eight primary and eight secondary rays, slightly thickened in the first half, intermittently and symmetrically arranged around the solar disk. The basic solar rays are directly detached from the solar disk, and the final outer length of all sixteen sun rays coincides with the outer periphery of the sun.

The diameter of the solar disk is one-sixth of the length of the shield. The ratio of the diameter of the solar disk to the length of the basic solar rays is one to two, and the ratio of the length of the secondary and basic sun rays is seven to eight. Under the shield is a red ribbon with a golden-yellow edge on which "Makedonija" is written with golden-yellow letters" 2 .

However, an agreement for the Arms was not reached, and the old Socialist emblem continued to be used. For details of the entire process, including all the proposals, see Jonovski (Jonovski 2018b).

The dispute with Greece over the use of the 16-rayed sun flag led to an embargo. The conflict over the Macedonian flag ended with the signing of the Interim Accord in New York on 13 September 1995, according to which the flag should be changed. The design of the new flag of the Republic of Macedonia was entrusted to Miroslav Grchev (Grčev 2011). During the process of designing the new flag, matching designs for the coats of arms were prepared for every proposal for the flag, but the Parliament did not pursue the matching proposal for the coat of arms (Figure 4).

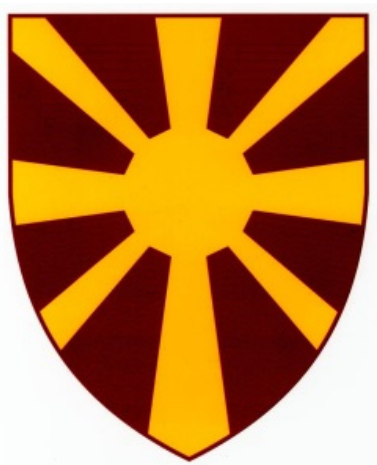

Figure 4. One of Miroslav Grchev's proposal for the coat of arms (1995).

Other proposals then followed: (1) adopting arms attributed to Macedonia in medieval Illyrian armorials; (2) the "heraldization" of the existing state emblem using the same elements and replacing the oval shield with an armorial shield; (3) keeping the existing state emblem but without the five-pointed red star. (Jonovski 2021a).

Finally, the last proposal was accepted, and on 16 November 2009, the new Law on the Coat of Arms of the Republic of Macedonia was adopted, with the old-new design of 
the state emblem (Figure 5). Article 2 of the Law on the Coat of Arms of the Republic of Macedonia described it as follows ${ }^{3}$ :

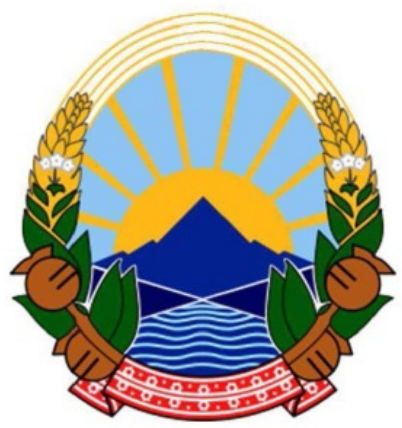

Figure 5. Coat of arms of the Republic of Macedonia adopted in 2009 after the removal of the red star.

"(1) The coat of arms of the Republic of Macedonia is a field surrounded by stalks of wheat that connect at the top, intertwined with poppy fruits and tobacco leaves, which are connected at the bottom with a ribbon embroidered with folk motifs.

(2) In the middle of the field is a mountain, and in the foothills a river flows, and the sun rises behind the mountain."

The last proposal was submitted by Jovan Jonovski, the herald of the Macedonian Heraldry Society (MHS). In December 2014, the Government accepted the proposed coat of arms: Or, a lion Gules, and above the shield a mural crown Or, based on 1581 work of Jerome de Bara, with minor changes (Figure 6). A mural crown with five towers on a gold diadem with rubies and pearl from Macedonia was added above the shield, in accordance with the Macedonian Civic Heraldic System. Due to the beginning of a political crisis, the adoption of the coat of arms was no longer a priority (Jonovski 2021a).

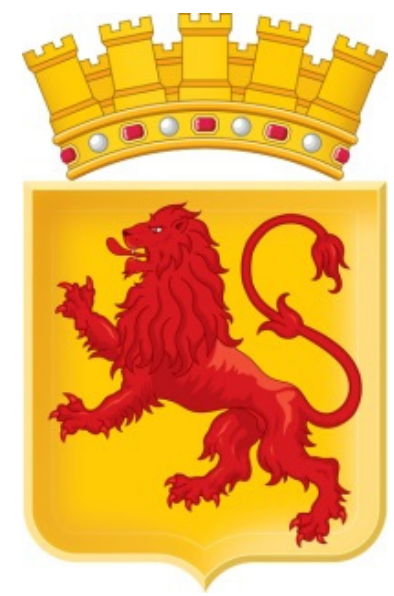

Figure 6. The 2014 proposal.

\section{Emblems of Municipalities, Urban and Rural}

Apart from the Capital, Skopje, which received a coat of arms in 1930s, many of the 32 municipalities in the Socialist Republic of Macedonia adopted emblems during the 1960s and 1970s.

Although they were not subjected to any form of regulation, the designs of these emblems conformed to the general socialist model, including landscape elements augmented with images of relevant industrial and agricultural equipment, mostly represented with a photographic realism alien to traditional heraldic arms (Jonovski 2019).

With the Law on territorial division of 1996, the Republic of Macedonia was divided into 123 municipalities plus the city of Skopje ${ }^{4}$. The Law allowed municipalities to adopt 
arms and a flag, only prescribing that they differ from those of the Republic of Macedonia, other municipalities in the country and in other countries, and international organizations. The registering office was the Ministry of Self-government ${ }^{5}$.

In 2004, the number of municipalities was reduced to 84 , and in 2013 , the number of municipalities became the current 80 plus the city of Skopje (holding a special status, which includes 10 municipalities). Municipalities in the Republic of Macedonia are categorized according to the status of the settlement where the seat of the municipality is located. Thus, there are urban municipalities with a seat in a city (over 3000 inhabitants) and rural municipalities with a seat in a village. The Law regulates the registration process of coats of arms, but there are no penalties prescribed for violating the law ${ }^{6}$.

The Ministry of Local Self-Government maintains a Register of coats of arms and flags of the units of self-government in the Republic of Macedonia. This regulation put the Republic of Macedonia in the category of countries with some form of "heraldic" authority (Antonov 2007).

The two laws and the practices arising from them can be summarized under three headings:

- Every Municipality has the right to have its own Coat of Arms and flag. The term Coat of Arms is not regarded in its actual heraldic meaning but is used generally loosely to mean an emblem. Some of the municipal emblem could not be classified as a Coat of Arms, even under the broadest definition of Arms.

- Municipalities have right to decide on the process on obtaining Arms and flag and it should be stated in the Municipality's Statute. The majority of municipal statutes stipulate that arms be chosen through a public competition. Nearly all such competitions require that "The arms should contain elements that represent the historical tradition, cultural heritage, landscape features, geographic, economic, and other characteristics of the municipality" (Одлука за начинот 2005).

- The Municipality then constitutes a commission, usually with no heraldic background, to oversee the competition and to propose the "winning" proposal to the Municipal Council.

The Register of the Coats of Arms and Flags of the Units of Local Self-Government, is kept at the Ministry of Local Self-Government. The process of registration is performed by an appointed clerk who only checks that the administrative procedures for registration are complete; the Municipality Statute has an Article regulating the obtaining of Arms and flag, and the process was as prescribed by it that any text in the Arms or flag is first written in Macedonian language and in the Cyrillic alphabet and only then in the language of the local minorities.

Then, an opinion is obtained from the State Office of Industrial Property that its design is not too similar to other registered Arms and Flags in the register 6ter of the WIPO. Once the paperwork is completed, the arms enter the Register as proposed, and a document is issued ordering that the Arms and flags can be used. However, since the Law does not prescribe any punitive measures, many Municipalities choose simply not to register their Arms and Flags at all.

Territorial heraldry in Macedonia appeared in practice during the socialist period, when "socialist heraldry" — using elements that are more ideological than geographic — had a strong influence. The most common elements were factories, factory chimneys, and cogwheels (symbols of the working class), fields or stalks of wheat (symbols of agriculture), and the sunrise (a symbol of a brighter future).

Most of the current emblems depict landscapes and stray far from classical heraldry. In a 2015 study (cf. Јоновски 2015, pp. 189-222), municipal emblems in Macedonia were classified into four categories according to their heraldic potential:

- Heraldic - coats of arms, according to the Macedonian Civic Heraldic System of the Macedonian Heraldry Society, considered heraldic or potentially so with only minor changes (15 emblems or 18\%) (Figure 7); 
- Potentially heraldic - coats of arms with heraldic elements that need to be provided with a heraldic blazon and the removal of texts (nine arms or 11\%) (Figure 8);

- Emblems with some heraldic potential-arms that could be emblazoned heraldically following the removal of non-heraldic items such as text and text scrolls bearing the name of the municipality (six arms or 7\%) (Figure 9);

- Those impossible to consider heraldic (52 arms or 65\%) (Figure 10).
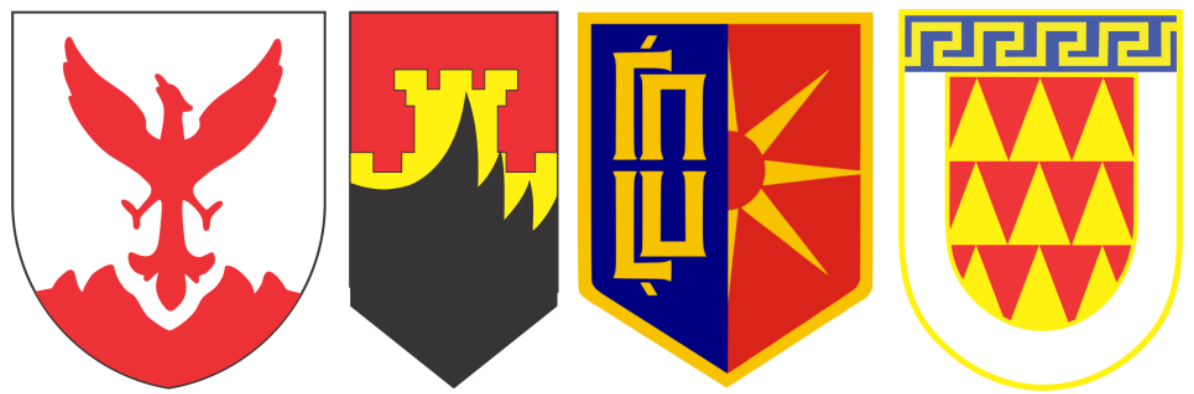

Figure 7. Sample of heraldic arms: Centar, Arachinovo, Gjorche Petrov, and Bitola.
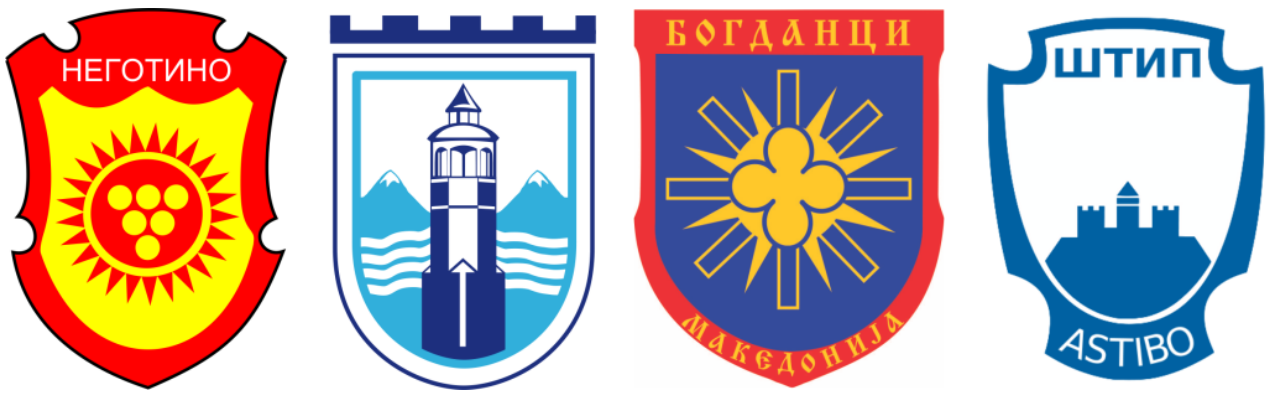

Figure 8. Sample of potentially heraldic arms: Negotino, Gostivar, Bogdanci, and Shtip.
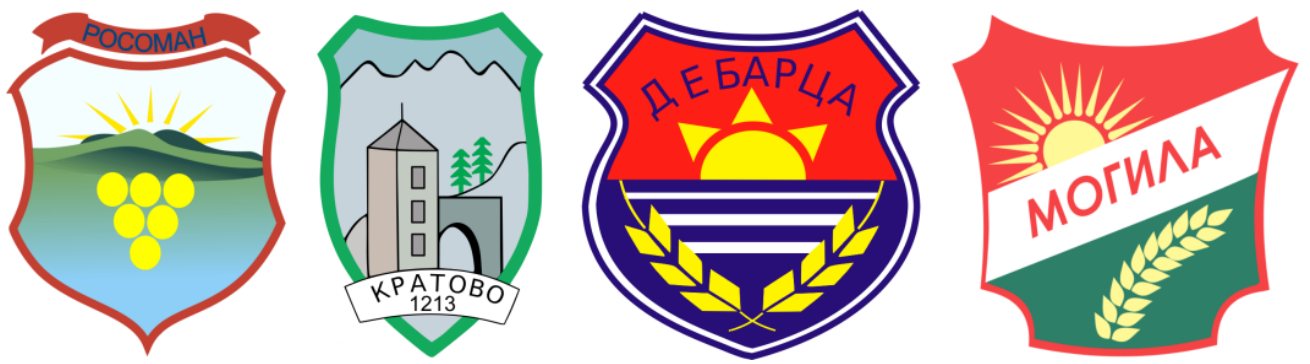

Figure 9. Sample of arms with some heraldic potential.
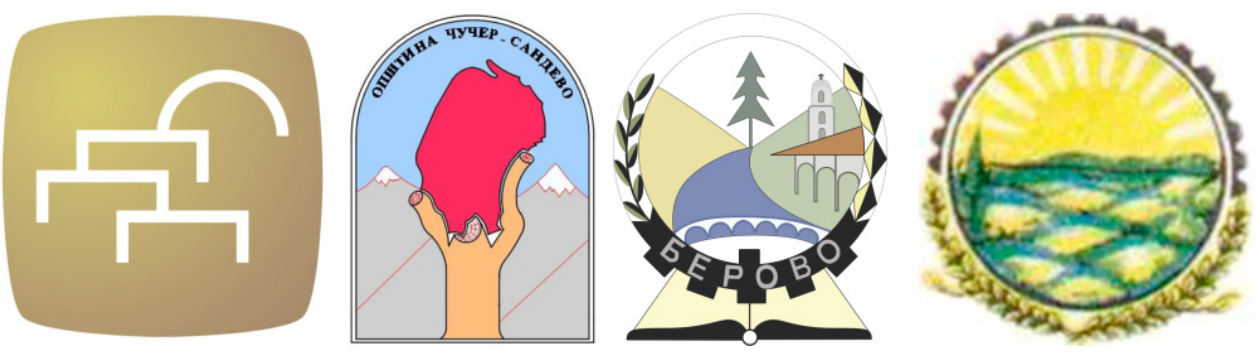

Figure 10. Sample of emblems impossible to consider heraldic.

Municipal emblems are often shown on monochrome or multi-colored flags. Most flags of local self-government units in the Republic of Macedonia were chosen through public competitions, which often required that the flag use the arms (Одлука за начинот 2005), and most have proportions of 1:2, also often a requirement. 
The full coat of arms or emblem appears on 53 flags $(68 \%)$, of which 26 have a monochromatic field in the colors of white (10), red (8), blue (6), and yellow (2) (the flag of the city of Skopje falls into this category); 20 flags have dichromatic fields in red-yellow (7), blue-white (6), red-blue (2), red-black (2), red-white (2), and green-yellow (1); and 7 flags have 3 or more colors (Јоновски 2015, p. 270).

Some flags (13) will have only some elements of the emblem, while 12 flags use neither the emblem nor any of its elements. Flags with three colors use yellow, black, and red (4); yellow, red, and green (2); and other combinations (one each).

The sun, a symbol of the "brighter future" in the socialist period, dominates the emblems of the municipalities and therefore the flags. Other flags contain sun rays. Landscapes appear on 31 emblems; 19 are quasi-heraldic and 11 appear in logos. However, the most frequent charge is the sun, appearing on 33 of the emblems and 35 of the flags, for a combined total of 37 emblems or flags with the sun.

In heraldry, the sun is normally represented in only one way, the "sun in splendor". It is commonly represented by a disk from which alternating straight and wavy rays emanate (the disk may have the features of a human face). The number of rays, which always emerge directly from the disk, can vary (Brooke-Little 1996, p. 198).

Various types of suns similar to those that appear on flags appear in current Macedonian municipal emblems and therefore should be considered vexillological representations of the sun. However, Macedonian municipal heraldry and vexillography use six main types of sun:

\section{(1) Solar disk (a roundel without rays)}

This type of sun appears on the coats of arms of four municipalities: Zhelino (Figure 11), where the sun, part of the landscape, is white over a blue horizon; Studenichani, where a yellow sun rises from behind a mountain on a blue background; Tearce, with a similar rising sun; and Kumanovo, where a circle (which the municipality perceives as a sun) forms part of a complex, non-heraldic composition.

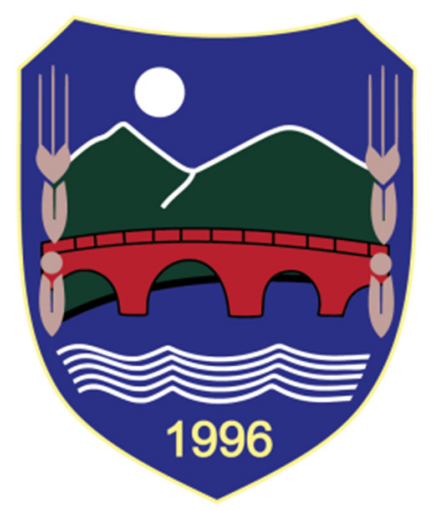

Figure 11. Arms with solar disk: Zhelino.

(2) Heraldic sun

As noted, the classic heraldic sun has a solar disk and (usually) alternating straight and wavy rays directly connected to the disk. The number of rays is not generally part of the blazon but subject to heraldic artistic interpretation, although the number of rays may have special importance for some armigers.

A sun of this type appears as a crest on the arms of Aerodrom (Figure 12) -in gold with 24 wavy rays (of which 13 are visible) - but no sun of this type occurs in the shield of any municipality's arms. 


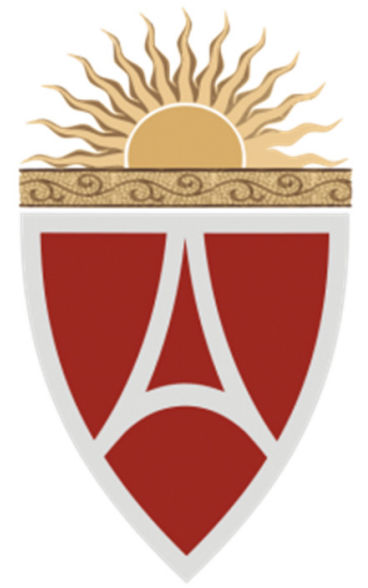

Figure 12. Arms with heraldic sun: Aerodrom.

(3) Sun with divergent rays

This type of sun has rays that spread radially from the sun disk; they may spread to the edges of the field (the shield) or be couped (and thus form an emblem).

This type of sun is found in 10 emblems, 8 of them showing a sunrise-in which part of the sun is below the horizon. The suns in five emblems have five or eight visible rays (Vasilevo, Karbinci (Figure 13), Kisela Voda, Pehčevo, Sopishte). The suns in the arms of Zrnovci and Resen have 12 and 13 visible rays, respectively. The sun can be found above the horizon in the arms of Butel, Demir Kapija, and Zelnikovo, where the sun is gold on a blue sky.

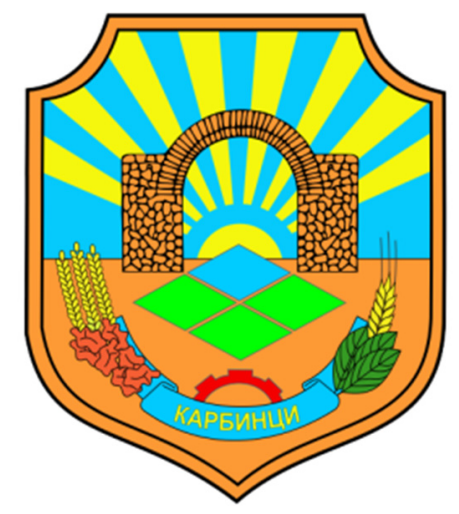

Figure 13. Arms with sun with divergent rays: Karbinci.

In such suns, the rays can emerge immediately from the disk or with a gap. On these emblems, half have suns with rays joined to the disk and half have rays separated from the disk. The rays can be couped or continue out to the field. Only one emblem, that of Resen, has a sun with couped rays.

(4) Sun with convergent rays

The sun with convergent rays is a disk from which rays of a defined length emerge. The rays can spring directly from the disk or be separated by a gap. Rays can be simple triangles or another shape (such as a diamond). However, if the rays begin with a semicircle, then they are considered a Kutlesh-type sun.

This type of sun is found on 10 emblems. On five, the sun is part of a symbolic landscape showing a gold sun on a blue sky (Gevgelija, Gradsko, Debarca, Negotino, and Novaci). On another five (Bogdanci, Gjorche Petrov, Krivogaštani, Rosoman, and Strumica (Figure 14)), the sun appears as an emblem in the field, and in two others, the sun is 
combined with another symbol. Three suns have rays joined to the disk and four have rays separated from the disk.

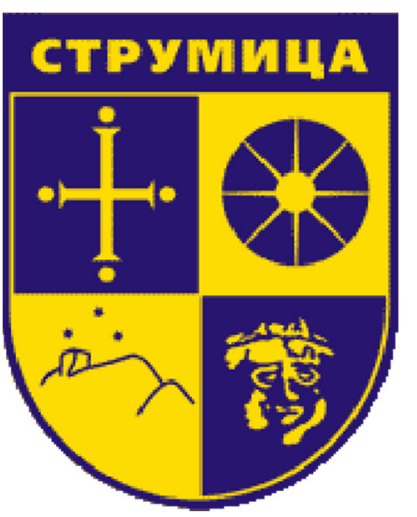

Figure 14. Arms with sun with convergent rays.

(5) Kutlesh type of sun

The Kutlesh-type sun, a special subtype of sun with convergent rays that was placed on 1992 national flag, is very popular and therefore is a separate type. Although this type has been found at other archaeological sites in the country, such as on the 12 ceramic wine glasses found near Samuil's Fortress in Ohrid, on the Macedonian shields in the tomb in Bonche dating from the 4th century BC, and others (Кузман et al. 2013, p. 676), it is named after the sun symbol on the lid of the sarcophagus of the royal tombs in Vergina (Kutlesh).

The Kutlesh-type sun is a small sun disk whose rays begin with a semicircular base and are longer than the diameter of the disk. It usually has an equal number of primary rays and shorter secondary rays (which end at the same distance as the primary rays, such that the rays' ends form a circle). Heraldically, it is actually a star, but in Macedonia, it is considered a sun with small disk. Suns of this type can have 6, 8, 12, or more rays (Јоновски 2015, p. 197).

The Kutlesh-type sun appears on five arms (Vinica, Ilinden, Konche, Mogila (Figure 15), and Rosoman). All of these show a sunrise in gold, four on a blue field and the other on red. Most of the suns have 16 rays of which fewer are visible; two suns have 26 rays.

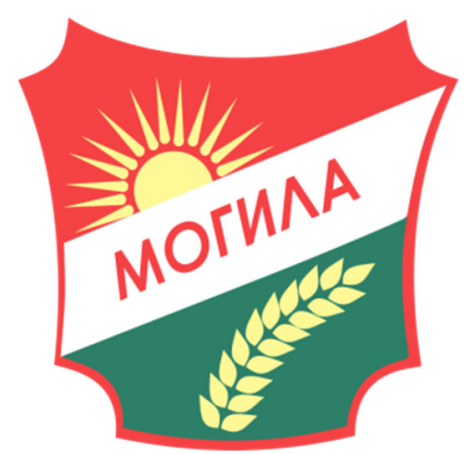

Figure 15. Arms with Kutlesh-type sun: Mogila.

(6) Linear or socialist sun

The sun in the arms and on the flag of the Republic of Macedonia is of this type.

Regarding the descriptions of the municipal arms created for the study of municipal arms containing the sun, they fall into five categories:

- No official description (Statute of the Municipality or other official documents) at all-municipal officials/employees do not recall having an official description of the arms, just an image of it; 
- No mention of the sun-usually the arms are described such as: "the local landscape", "surroundings", "geographic specifics";

- The contents of the arms are merely listed-describing the arms by listing the elements: "On the Arms of the Municipality there are: field, sky, sun ... ";

- The sun is described as a sunrise-e.g., the description says: "Behind the mountain there is a sunrise";

- A more detailed description - the content of the "arms" is described as "A half of the sun with 13 visible rays coming out of the sun, the rays being wavy".

Sometimes, the official description gives the meaning of the element of the coat of arms. In the municipality of Butel, the description reads: "The sunrise symbolizes the appearance of the new Municipality of Butel".

The three rays in the arms/emblem of Zrnovci symbolize its three settlements: Zrnovci, Morodvis, and Vidovishte. The municipality of Ilinden describes, "There are 12 rays representing 12 populated places". In the municipality of Krivogashtani, the arms "contain a sun with eleven rays with eleven stars that mark the eleven inhabited places" in the municipality.

In the Municipality of Vasilevo, it is also perceived as a "symbol of the desire for light and freedom." For Kumanovo, the sun represents "warmth, hospitality set on a red background, a symbol of revolution, youth, and driving force." In the Skopje municipality of Gjorche Petrov, the sun is "a symbol of development, perspective, happy and positive life".

Of the 80 municipalities in the Republic of Macedonia, 37 (46\%) have a sun in their arms/emblems and/or flag. On $24(30 \%)$, the sun is in the coat of arms on the flag; 3 municipalities have the sun only in the coat of arms; 4 have a sun only in the flag; and 5 municipalities have different suns in the arms and flag. Counting these as different suns, the total number is 42 . Of these 42 suns, 22 (19 on arms and 3 on flags), or $52 \%$, are depicted only as part of the landscape or as a sunrise. This comes as no surprise, as the sun in the national coat of arms is defined as "the sun rising behind the mountain," and the anthem also sings of "the birth of new sun"- the sunrise. Another four arms (or 9\%) depict a fully risen sun for a total of $61 \%$ showing the sun as part of the landscape.

\section{Macedonian Civic Heraldic System}

According to the law, all local self-government units (municipalities) (LSGU) in the Republic of Macedonia, can have coats of arms and flags, where the term "coat of arms" is used to denote the official emblem of the municipality, regardless of whether it is a heraldic coat of arms, some kind of free composition, or a logo. Most of the current emblems depict landscapes and stray far from classical heraldry. A high percentage are non-heraldic and landscape socialistic "heraldry". Out of 83 Arms, 52 or $65 \%$ are non-heraldic nor can they be even made heraldic. Together with the hardly heraldic 6 or $7 \%$, this makes $72 \%$ of emblems non-heraldic. The forms of shield adopted to bear the municipal arms and quasi-armal emblems in official depictions fell into 10 distinct types, of which what may be called the "Spanish" type and the "Renaissance" type were the most common, with 16 and 15 examples, respectively (the names of the types of the shield used in the heraldry in Southeast Europe) (Јоновски 2015, pp. 213-16).

In order to harmonize the design of arms, the Macedonian Heraldry Society (MHS) has adopted rules that make up a system by which arms can be created and adapted. This Macedonian Civic Heraldic System (MCHS) complies with the laws of the Republic of Macedonia prescribed by the Local Government Act and the Territorial Organization of Local Self-Government. The MCHS, apart from civic heraldry, also covers state heraldry: the state coat of arms and the state seal. The state coat of arms is composed of a shield and the state mural crown. The state mural crown stands for expressing the highest status of the state. It is a symbol of the republican order and represents its territorial integrity and sovereignty (Figure 6). The state mural crown can be used within the military-heraldic system of the Army of the Republic of Macedonia and the police and the heraldic system of the Ministry of the Interior (Nacevski 2014). 
The MCHS standard form of shield is of a plain late Gothic type with a large radius of the lower sides, where the curve starts at the half-height of the shield. The ratio is $6 \times 5$ (Figure 16). This shield is similar to the shield on the Arms of Mavrovo-Rostushe (Јоновски 2015).

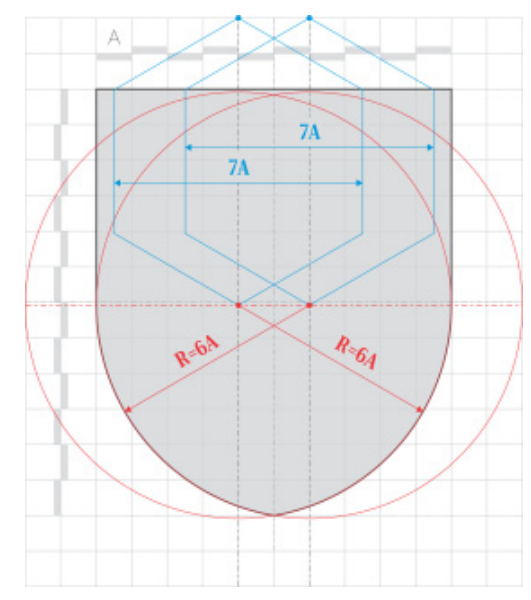

Figure 16. The MCHS standard shield.

The MCHS prescribes the form of four general types of emblems: (1) three levels of armorial achievement (lesser, middle, and greater), (2) heraldic flags, (3) heraldic badges, and (4) heraldic seal-designs. As can be seen in Figure 17, the middle achievement is distinguished by a type of mural crown set over the shield, and the greater achievement is distinguished by the further addition of a type of vegetal wreath, involving various forms of leaves and fruit and indicative of historical associations. These achievements lack both of the external types of emblems common in civic and state arms in most of Europe, as well as their insignial supports: crests set on helmets and supporters set on compartments).
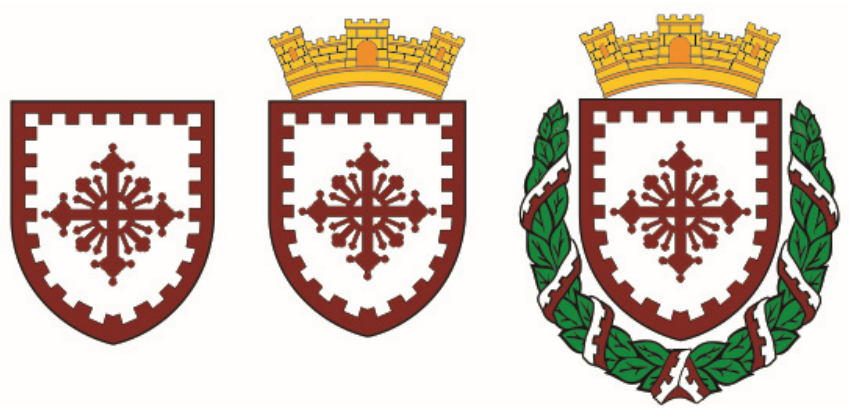

Figure 17. Achievements of Radovish.

The crowns' forms are indicative partly of the rank and partly of the situation of the municipality (with urban or rural seats). The crowns fall into two general types: one mural (the normal type) and one palisade (with only one example to date). The mural type, always gold throughout, is composed of a wall normally set between three equal towers and a red central gate, set on a plain gold band called a "diadem".

The crown of the capital city, Skopje, is officially distinguished by the placement of a row of rubies and pearls on its diadem and unofficially distinguished by four equal towers and the suppression of the central gate (Figure 18) (Nacevski 2014). 


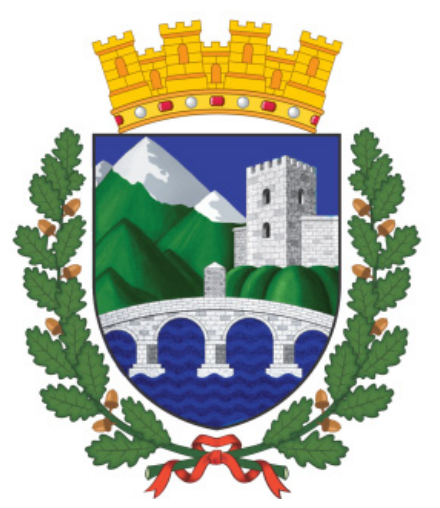

Figure 18. The arms of Skopje, unofficial (A. Kurov, J. Jonovski).

The diadems of the historic capitals of Ohrid and Prilep are officially distinguished by a row of rubies alternating with pearls (Figure 19) (Јоновски 2015). The rural crown represents a palisade crown made up of a series of seven visable pales placed on a golden diadem (Figure 20).

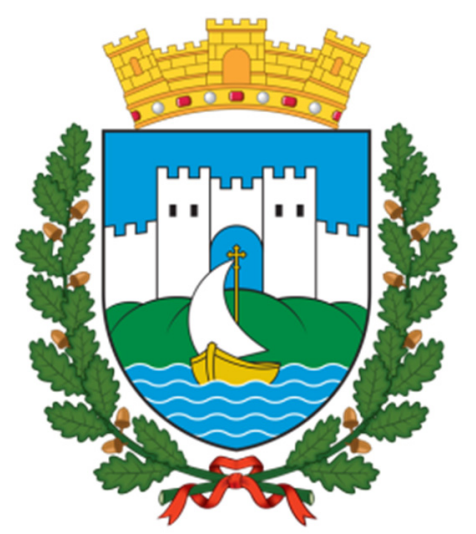

Figure 19. Coat of arms of Ohrid.

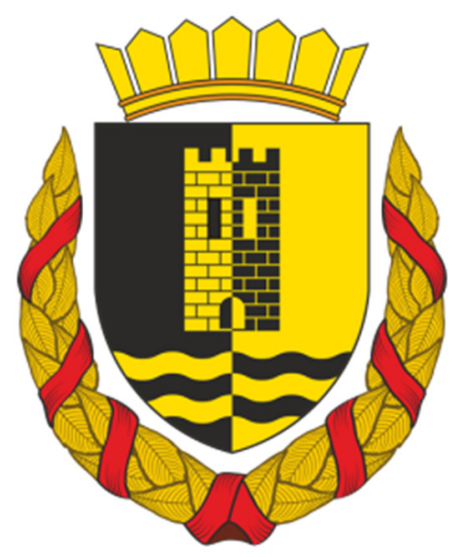

Figure 20. Palisade crown of Novo Selo.

The arms of the LSGU can have a heraldic wreath, a motto on a scroll, and decorations if such are owned by the armiger. The wreath highlights the uniqueness of each municipality; the wreath of historical capitals consists of two oak twigs. Skopje city municipalities have a wreath of two linden leaf branches (Figure 21a). Radovish has a wreath of tobacco leaves, Novo Selo a wreath of chestnut leaves, Ohrid a wreath of oak branches, Sveti Nikole a wreath of wheat class (Figure 21b), Demir Hisar a wreath of beech and Cheshinovo-Obleshevo a wreath of rice class. 


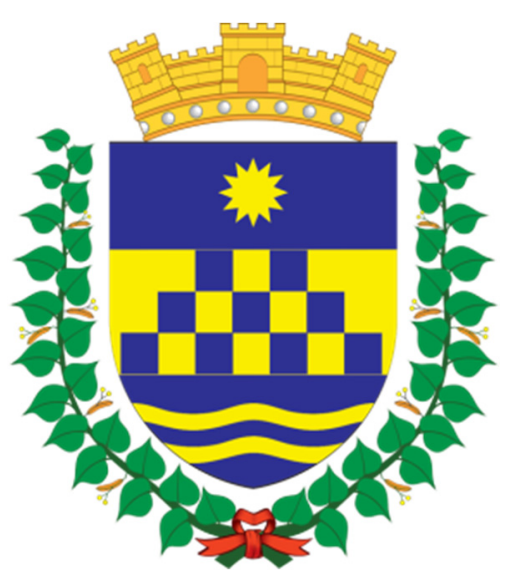

(a)

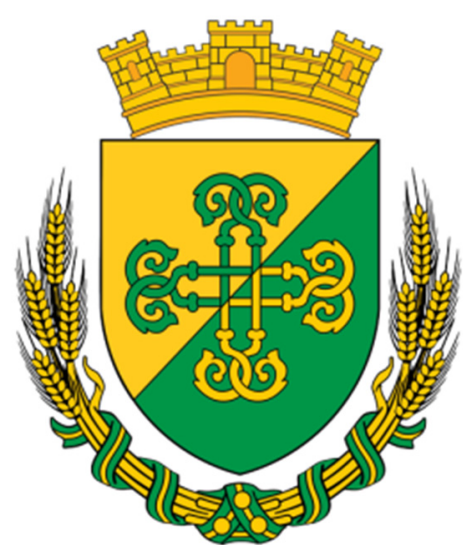

(b)

Figure 21. (a) Coat of arms of Karposh, unofficial; (b) Coat of arms of Sveti Nikole (2014-2018).

The purpose and use of each of the achievements of the Arms are prescribed by the Rulebook for the Use of Arms and the Flag (Правилник 2013).

Heraldic badges can be based on the Arms but may also be independent of them. Heraldic badges in no way constitute a complete copy of the lesser achievements and are worn only as insignia of the staff in the administration of the municipalities.

The seals of municipality use the middle form of achievements. This is designed to highlight the official status of the seal and is in accordance with the use of the forms of Arms prescribed by the Rulebook for their use.

The acceptance of the MHS as an expert body in the local heraldry was slow. In 2008, MHS delegation participated in the analysis of the proposals for the coat of arms of the municipality of Kriva Palanka. The Commission for determining the coat of arms and the flag of the municipality chose from the received proposals at the competition. They also conducted a heraldic analysis.

The Macedonian Civic Heraldic System was passed in 2013, and the new system was applied to the achievements of the municipality of Radovish. Then followed the coat of arms of the Municipalities of Novo Selo, Ohrid, Sveti Nikole, Cheshinovo-Obleshevo, and Demir Hisar, designed by members of the MHS. The coat of arms of the municipality of Probishtip contains the formal elements of the system but is of a different style. In 2018, Sveti Nikole has returned to the old non-heraldic emblem.

\section{Personal Heraldry}

There is no known family or patrilineal arms in Macedonia before the end of 20th century, when there was increasing interest, and many individuals and families are acquiring arms. In the Republic of Macedonia, anyone who has enough interest and commitment can have a "burger" coat of arms. Burger coats of arms are without elements indicating status and position, such as supporters, large mantles, crowns (except crest coronet) and medals and symbols of knightly ranks. The legislation in the Republic of Macedonia regulates only municipal coats of arms. In consequence, personal arms are not formally regulated.

The Macedonian Heraldic Society (MHS) maintains a Register of Coats of Arms. The register exists in digital form and is published on the society website and in Macedonian Herald. It contains personal, corporate, and municipal coats of arms, mostly designed by members of the MHS. The first coat of arms, the coat of arms of MHS, was registered on 1 October 2004, and until the current one registered on 7 July 2021, the registry contained a total of 58 coats of arms: 39 personal, 8 organizational, 6 municipal coats of arms, as well as 5 of position (Figure 22). 


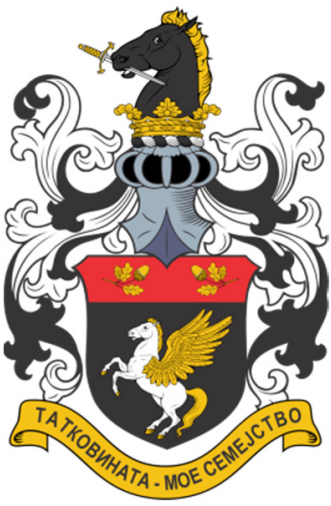

(a)

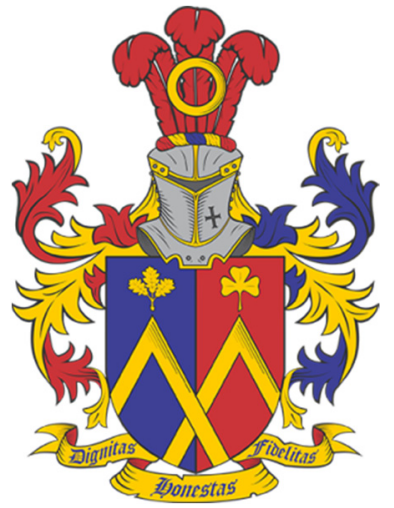

(b)

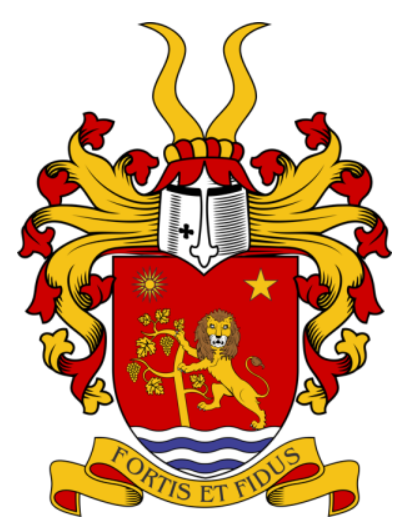

(c)

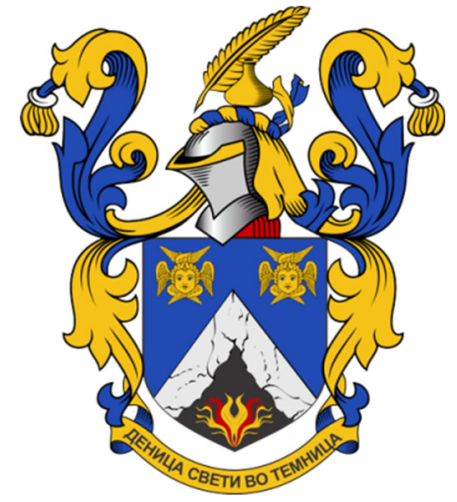

(d)

Figure 22. Samples of personal heraldry, coat of arms of (a) Ivan Nacevski; (b) Aleksandar Janchevski; (c) Bojan Kocevski, (d) Mojso Popovski.

The MSH creates new arms and crests in whose designs the traditional conventions of European heraldry are respected, along with some conventions peculiar to Macedonia. The inclusion of state emblems, including the lion rampant and the Kulesh type of sun, is generally avoided. Pretentious designs, suggesting ties to distinguished historical lineages and dignities, are also avoided.

In Macedonian heraldry, in contrast to that of some other countries, the forms of helmet do not indicate any form of status, and this is also true of coronets, which are used only as crest-bases. Supporters-which in many countries are indicative of personal achievements of a relatively high status-are not employed at all.

The procedure for the registration of personal armories by the MHS begins with the submission of a petition for a particular design, expressed in blazonic terms. This is then examined from an expert perspective, and if it is found acceptable, based on both the conformity of its design to the traditional conventions and on the more general rule of uniqueness within a particular heraldic jurisdiction (in this case, that of Macedonia), the blazon is entered in the Register of the Society. Next, a certificate of matriculation called a matricula (such as that in Figure 23) is issued to the petitioner.

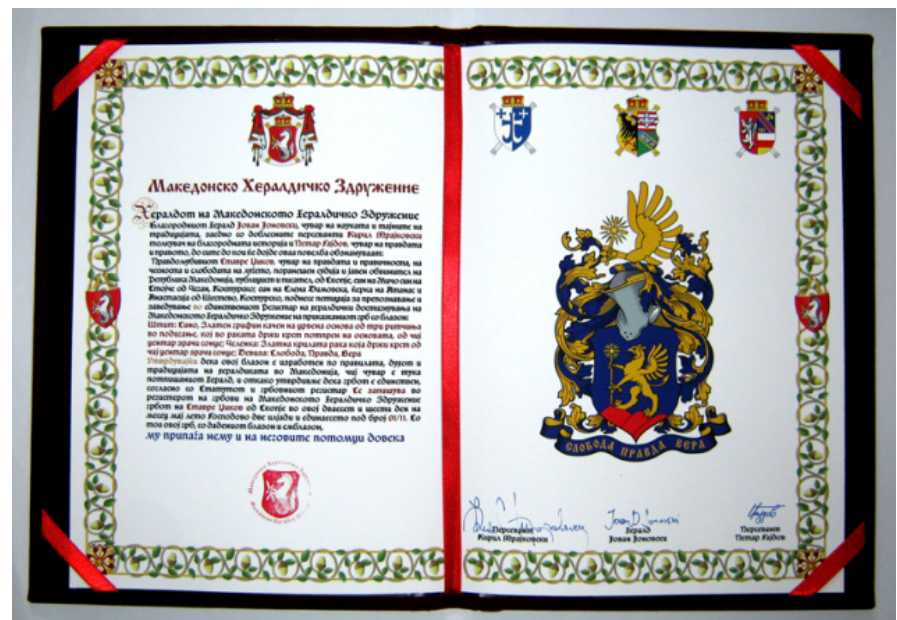

(a)

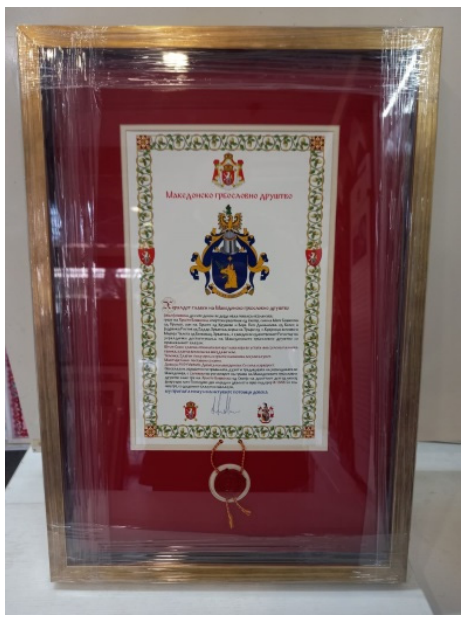

(b)

Figure 23. Matricula (a) Hardcover version; (b) Framed version.

Thus, both a formal record of registration and a formal certificate testifying to this are created, making the registration a public act that should be accepted by all other heraldic associations, including state heraldic authorities where they exist. 
The armories registered by the MHS are not intended to represent any nobiliary status and might be compared to the "burger" or "bourgeois" type of older heraldic systems. Accordingly, the MHS will not include in its Register insignia of foreign honours of any type, and the matriculation cannot be used to claim any legal status within Macedonia other than that of armiger. In the case of arms already used outside Macedonia, however, any augmentations, quarterings, or marks of cadency that can be properly documented may be included in the matriculated form. The unilateral addition to the registered armories is prohibited and may result in their deletion from the Register.

In the Register and in the matriculas based upon it, the 39 personal arms currently recorded have been represented on 5 different forms of shield: 26 (or 66\%) are of the standard late-Gothic type, 3 are on Renaissance shields, 2 are on Spanish shields, and 1 each are on the German and Polish forms. Of the arms, all but one are unmarshalled, and that one includes a simple quarterly design.

The distribution of tinctures in these coats is as follows: 10 have the combination of gules and Or, 7 have the combination gules and argent, 6 have the combination azure and Or, 5 have the combination azure and argent, 4 have the combination sable and Or, 4 have the combination sable and argent, 2 have the combination vert and argent, and 1 has the combination vert and Or.

The most frequently occurring non-geometrical figures, including those in the crest as well as the arms, are the following: 8 lions, 5 horses, 4 crosses, and 3 wolves. Of the geometrical figures, including both the "ordinaries" and the "subordinaries" that were included in 19 (or 60\%) of the arms, there were 7 chevrons, 5 champagnes or bases, 3 bends, 2 chiefs, 2 saltires, 1 bordure, and 1 fess.

The authors of the recorded blazons and artists of the corresponding emblazonments were the following: (1) Jovan Jonovski (25 blazons and 21 emblazonments); (2) Ivan Nacevski (6 and 5), Stojanche Velichkovski (2 of each), Kosta Stamatovki (1 and 2), Aleksandar Gizharovski (1 of each), Petar Gaidar (1 blazon), Matej Bogdanovski (2 emblazonments), and Alexander Kurov (1 emblazonment). Five of the achievements were designed by nonmembers. Some former members have been designing new armories without bothering to register them.

All of the achievements were provided with mottos, 26 in Latin, 8 in Macedonian ( 2 written in Glagolitic letters), 1 in Old Slavonic, and 1 in Polish.

\section{Heraldic Thought in the Republic of Macedonia}

Interest in heraldry in the Socialist Republic of Macedonia was active during the 1960s and early 1970s, after which it declined. It resurfaced in 1990 when, with the collapse of Yugoslavia, the question of a possible coat of arms for the future independent Macedonia arose (Jonovski 2020).

At the beginning of the 21st century, Macedonian heraldic thought entered a new stage. Heraldry, treated as an auxiliary science was thought together with other auxiliary sciences of history in the subject of the same name in one semester at the Faculty of Philosophy-Institute of History since the 1960s.

\subsection{Macedonian Heraldry Society}

A group of interested people with modest heraldic knowledge, but with great love for heraldry, vexillology, and phaleristics, gathered around web site "Heraldry in Macedonia" created by Jovan Jonovski in 2000. The website initially posted information and images from the book Coats of Arms of Macedonia by Aleksandar Matkovski (Матковски 1990).

From this group, on 15 June 2003, the Macedonian Heraldry Society (MHS) was formed. It concentrated on the study of heraldry as well as vexillology, phaleristics, and emblematics. The Society's aim was to raise heraldic awareness through the popularization of the heraldry, research on the heraldic heritage of Macedonia, designing coats of arms, flags, and decorations, and establishing a heraldic register. Jovan Jonovski was elected president and herald, Snezhana Filipova, MA as vice president, and Petar Gajdov as 
secretary. In 2004, the vice president, Snezhana Filipova, introduced the elective subject of heraldry in the Middle Ages program of the Institute of Art History.

The first lecture of the MHS was delivered by guest speaker André Wocial from France, in April 2004. The next lecture was held at the on International Museum Day in May 2005 at the Museum of Macedonia titled "The Wonderful World of Heraldry". At the same event, the first issue of the Macedonian Herald — the MHS gazette—was promoted, in which articles were published in Macedonian and English. On International Museum Day in May 2007, a lecture was delivered at the Museum of Macedonia and the promotion of the second issue of The Macedonian Herald.

During 2007-2008, in cooperation with the Museum of Macedonia, several lectures and workshops on heraldry took place, in coordination with the MHS member Lena Angelkoska. Lectures were held by guest lecturers: Dr. Stoyan Antonov from Plovdiv (Bulgaria), Prof. Dr. Vojislav Ivanisevic from Belgrade (Serbia), Prof. Dr. Nikos Causidis from Skopje, and Prof. Dr. Ivan Balta from Osijek, (Croatia). In addition, lectures on heraldry begun at the Faculty of Philosophy, Institute of Art History with Archeology, which were held by Dr. Snezhana Filipova, as an optional subject.

In March 2009, a permanent exhibition of heraldry in Macedonia at the Museum of Macedonia was opened with a lecture and a promotion of the third issue of The Macedonian Herald. The main advisor in collecting and selecting the material was the President of the MHS, Jovan Jonovski, MTh. That same year, a documentary was recorded on heraldry in Macedonia for Macedonian Television with Jonovski and Filipova.

The same year, Jonovski was appointed as a member of the Commission for decorations of the President of the Republic of Macedonia, Gjorge Ivanov. Shortly afterwards, a team from the MHS led by Jonovski, with Stojanche Velichkovski and Petar Gajdov, engaged in designing the Coat of Arms of the President (Figure 24).

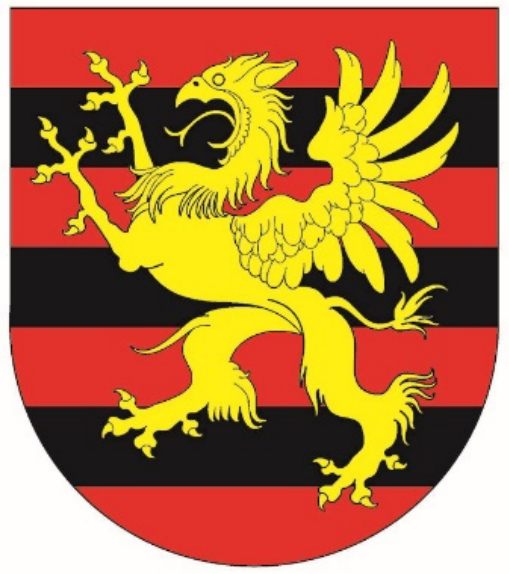

(a)

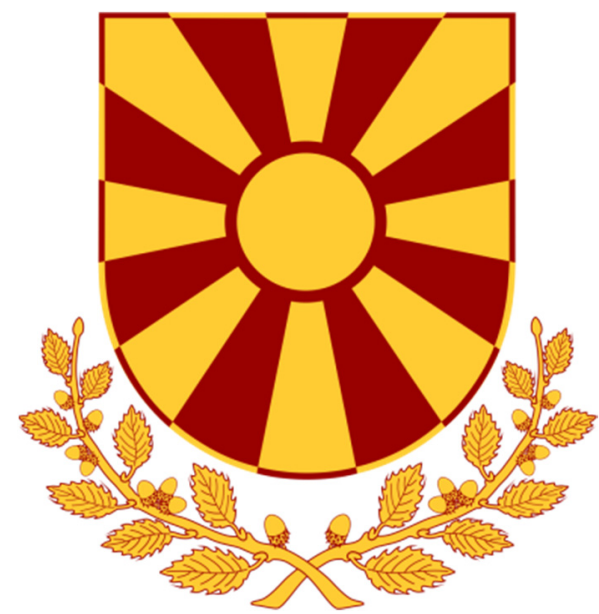

(b)

Figure 24. (a) Proposal for the arms of the President of the Republic of Macedonia; (b) Official arms of the President of the Republic of Macedonia.

Jonovski and Velichkovski worked of the coat of arms of the Macedonian Orthodox Church-Archpishopric of Ohrid (Figure 25).

The lectures and workshops on heraldry at the Museum of Macedonia continued into 2010. Afterwards, they continued in different locations. 


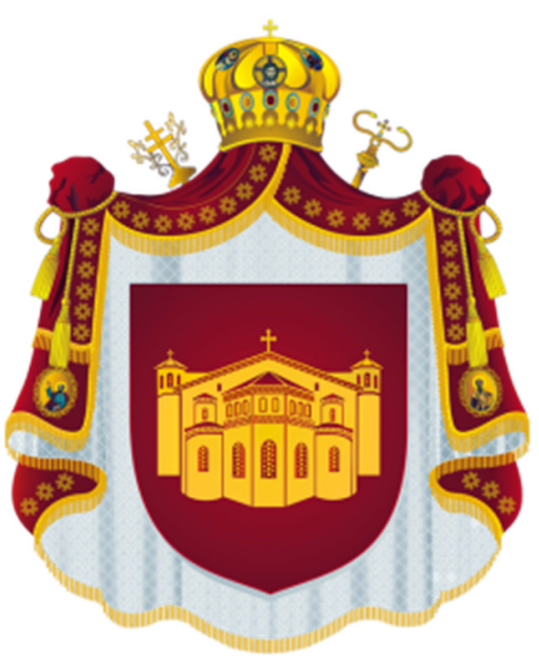

Figure 25. Coat of arms of the Macedonian Orthodox Church-Archbishopric of Ohrid.

At the XXIX International Congress of Genealogical and Heraldic Science in Stuttgart, Germany on the 14th of September 2010, the MHS became a full member of CIGH, and on 2 August 2011 at the XXIV International Congress on Vexillology in Washington, DC, USA, the MHS was accepted for a full membership in the FIAV (International Federation of Vexillological Associations, Huston, Texas).

In 2014, the Government considered a possible alternative version of the armorial bearings of the Republic of Macedonia. In the process of defining the arms and its visual design, Jonovski was the main consultant, who, together with Kosta Stamatovski, drew the vector image of the arms, which was based on the work of Jerome de Bara.

In 2015, the book Symbols of Macedonia was published, in which Jonovski deals with theoretical heraldry, vexillology, phaleristics, and Hymnology. The historical development of the coats of arms, flags, orders, and the anthem of Macedonia is given. That same year, Jonovski enrolled in doctoral studies at the Institute of National History with the theme "The Sun and the Lion as Symbols in Heraldry and Vexillology of Macedonia".

In 2016, Jonovski also worked on a series of seven documentary shows on the symbols of Macedonia, three of which he appears on as an author: the Heraldry, the Land coats of arms, and the Eagle and the lion as symbols. Documentaries were broadcasted in 2017. Ivan Nacevski and Kosta Stamatovski participated in the recording of the documentaries.

On 15 July 2018, on the 15th anniversary of its foundation, the Macedonian Heraldry Society was dissolved. During the 15 years of existence, the members of the Executive Board were:

- Dr. Jovan Jonovski, President (2003-2018);

- Dr. Snezana Filipova, Vice President (2003-2007)—Professor at the Department of Art History at UKIM, Skopje;

- Mr. Kiril Trajkovski, Vice President (2007-2012)—Curator-adviser in the Museum of Macedonia;

- Petar Gajdov, Secretary (2003-2012), Vice President, (2012-2015) - Lawyer;

- Aleksandar Gizharovski, Secretary (2012-2015)—Software engineer (Jonovski 2018a).

On the same day, the Macedonian Heraldic Society continued the work with the following Executive Board: Dr. Jovan Jonovski, President; Dr. Ivan Nacevski, Vice President; and Gen. Dr. Pavle Arsoski, Secretary.

The first issue of the Journal of the Association of The Macedonian Herald was published in 2005 on 16 pages multiplied on a b/w photocopier, as a bilingual journal, in Macedonian and English. The first circulation contained 100 copies, increasing many times over the years. The second issue came out in 2007 on 16 pages but in color and in 200 copies. The third issue came out in 2009 in color and on 28 pages in 500 copies. From the fourth issue, The Macedonian Herald began to be published regularly every year until the tenth issue 
appeared in 2016. From issue 11 from December 2018 (40p), The Macedonian Herald has an international editorial board and is issued twice a year (72p).

The articles about heraldry, vexillology, phaleristics, symbolistics, etc., are peer reviewed. Heraldic articles include a total of 34 authored by Jovan Jonovski (with 19 articles) and Ivan Nacevski (11), followed by Stojanche Velichkovski (3), Aleksandar Gizharovski (3), and 8 other authors with 1 article each.

\subsection{Macedonian Heraldry Authors in Twenty-First Century}

Aurthors that are writing on heraldry in general and specifically in Macedonia are several (Јоновски 2019b).

Snezhana Filipova

Prof. Dr. Snezhana Filipova (1965), Institute of Art History, Vice President of the Macedonian Heraldry Society (2003-2007), started publishing articles in the same year (Filipova 2005, 2007), and in 2015, seven previously published texts related to heraldic motifs on frescoes and one with the Mijak flag were published in the book Studies on Macedonian Heraldry (Филипова 2015).

Snezana Filipova defines heraldry as "the study of the origin, development and application of coats of arms. It is based on a set of rules according to which figures, objects and their placement in the shield are arranged, drawn, described (blazoned)" (Филипова 2015, p. 7).

\subsection{Boban Petrovski}

Prof. Dr. Boban Petrovski (1972) is a professor at the Faculty of Philosophy-SkopjeInstitute of History of the subject Auxiliary Historical Sciences and at the Faculty of Pedagogy-Skopje-in the subject of Heraldry. Petrovski published the book Heraldry and Insignia in 2009, which is the first modern heraldic textbook, intended as a coursebook for a subject with same name at the European University. The book provides more modern understandings of heraldry and the coat of arms. It also presents the heraldic jurisdictions in Europe, as well as an overview of the heraldists from the neighboring countries (Петровски 2009).

Boban Petrovski mainly adheres to Matkovski's definition: "auxiliary historical science, which deals with the study of the origin, historical development and artistic making of coats of arms in general or on individual coats of arms" (Петровски 2009, p. 11). Petrovski fully accepts this definition with insignificant interventions (Петровски 2009, p. 34).

\subsection{Jovan Jonovski}

Dr. Jovan Jonovski (1971), herald, is President of the Macedonian Heraldry Society (2003-2018) and the Macedonian Heraldic Society (2018-) and an Associate Member of the International Academy of Heraldry. He is a member of the International Commission of Order of Chivalry, as well as a member of the Order and Medals Commission of the President of the Republic of Macedonia (2009-2019). Jonovski has published 14 articles, as well as a Macedonian heraldic terminological dictionary in The Macedonian Herald, in which heraldic terminology in Macedonian is defined in 10 issues so far. For Jonovski's full bibliography, see (Jonovski 2021b). Jonovski participates in international congresses in heraldry (Stuttgart 2010; Cieszyn 2012; Oslo 2014; Glasgow 2016; Cieszyn 2018).

In 2015, the book Symbols of Macedonia by Jovan Jonovski was published. In addition to the theoretical part, it also contains an analysis of the historical coats of arms related to Macedonia, as well as a basic analysis of the lion and the sun (Јоновски 2015). In 2018, Jonovski defended his doctoral dissertation entitled "The sun and the lion as symbols in the heraldry and vexillology of Macedonia" at the Institute of National History under the mentor prof. Dr. Dragica Popovska. The dissertation was published in its entirety in 2019 (Јоновски 2019а).

Jonovski gives this collective definition: "a science, that deals with the study of: the origin, historical development and the legal relationships among armories belonging to 
individuals, families or communities; the principles and rules according to which the figures in the shield are arranged, drawn, described and their artistic representation and description on the coat of arms" (Јоновски 2019a, p. 32).

Jonovski gives a collective definition (of all proeviously given definition by heraldrist in Macedonia): "the coat of arms is a symbolic representation that indicates the coat of arms, ie some of his rights and aspirations, expressed by artistic means that are painted on a shield, according to heraldic rules, described with a blazon" (Јоновски 2019a, p. 20).

\subsection{Ivan Nacevski}

Dr. Ivan Nacevski (1985), Dentist, Vice President of the Macedonian Heraldry Society. Nacevski started publishing articles in The Macedonian Herald in 2011. He has concentrateds on the coats of arms of Macedonia (land and European coats of arms) (Nacevski 2015) and the attributed coats of arms of Alexander the Great (Nacevski 2016) as well as the terminological dictionary. (For full bibliography see, Nacevski 2021).

\section{Conclusions}

Heraldry in the Socialist Republic of Macedonia had its modest start in the 1960s and 1970s, followed by almost two decades of blackout. The interest in heraldry resurfaced in 1990 at the dissolution of Yugoslavia and the question of the possible coat of arms of the new independent Macedonia, looking at historical coats of arms. The Republic of Macedonia obtained its new "old" "coat of arms" by removing the five-pointed red star in 2009. With the change of the Law on the municipalities in 1997, all 120 municipalities were given right to have a "coat of arms". Although this was not heraldically regulated, some arms were heraldic (in most cases, a mainly non-heraldic emblem).

The next stage in the development of Macedonian heraldry began in the early twentyfirst century, especially through the creation in 2003 of the Macedonian Heraldry Society as a body to promote interest in heraldry generally and the heraldic heritage of Macedonia in particular. In its journal, The Macedonian Herald (2005), a dozen authors have published articles on heraldry, among the other similar sciences and disciplines. This, together with an additional four books on heraldry published in Macedonian in the last two decades, has surpassed the previous knowledge of heraldry by a lot.

The use of personal arms developed in the twenty-first century, mainly through the work of the MHS and its Register of coats of arms. The development of the Macedonian Civic Heraldic System busted the civic heraldry by creating heraldic arms for the municipalities in the Republic of Macedonia.

Funding: This research received no external funding.

Institutional Review Board Statement: Not applicable.

Informed Consent Statement: Not applicable.

Data Availability Statement: Not applicable.

Conflicts of Interest: The author declares no conflict of interest.

\section{Notes}

1 Група, пратеници. 1992а. Предлог за донесување закон за грбот на Република Македонија со предлог на закон, 20.7.1992. State archive of the Republic of Macedonia, Collection 1304: Parliament of Republic of Macedonia (1990-1994) Session 41, points 4,5,6 Box 46. [Group of Members of Parliament, Proposal for enforcing a Law on the Coat of arms of the Republic of Macedonia with the proposed text of the Law].

2 Група, пратеници. 1992b. Амандман на Предлог за донесување закон за грбот на Република Македонија, поднесенод група пратеници, Петковски, Крстевски иПоповски, 30.7.1992. State archive of the Republic of Macedonia, Collection 1304: Parliament of Republic of Macedonia (1990-1994) Session 41, points 4,5,6 Box 46. [Group of Members of Parliament, Amendment to the Proposal for enforcing a Law on the Coat of arms of the Republic of Macedonia submitted by group of Members of Parliament: Petkovski, Krstevski and Popovski]].

3 Службен 2009. The Official Gazette of the Republic of Macedonia. Службен весник на Република Македонија $138 / 09$. 
Службен 1996. The Official Gazette of the Republic of Macedonia. Службен весник на Република Македонија 49/96.

Службен 1995. The Official Gazette of the Republic of Macedonia. Службен весник на Република Македонија 52/95.

Службен 2004. The Official Gazette of the Republic of Macedonia. Службен весник на Република Македонија 55/04.

\section{References}

Antonov, Stoyan. 2007. Heraldry as a System of Symbols. lecture, 1.11. Skopje: Museum of Macedonia.

Brooke-Little, J. P. 1996. An Heraldic Alphabet. London: Robinson Books.

Grčev, Miroslav. 2011. In Search of the New Flag. In Macedonian Herald 5. Skopje: Macedonian heraldry Society.

Народното. 1946. Народното собрание на Народна Република Македонија изгласа неколку закони важни за нашиот народ. Нова Македонија, July 28, [The Peoples' Assembley of the Peoples Republic of Macedonia, passed on several important laws for our people, Nova Makedonija].

ЈоновскиЈован. 2015. Симболите на Македонија. Скопје: Силсон, [Jonovski, Jovan, Symbols of Macedonia, Skopje: Silsons].

Jonovski, Jovan. 2018a. History of the Macedonian Heraldy Society. Macedonian Herald 11.

Jonovski, Jovan. 2018b. The Coats of Arms and Other Forms of State Emblem Proposed for the Republic of Macedonia, and the Process of Their Adoption, 1992-2014. Genealogy 2: 52. [CrossRef]

Jonovski, Jovan. 2019. Territorial Heraldry in the Republic of Macedonia and Macedonian Territorial Heraldic System.

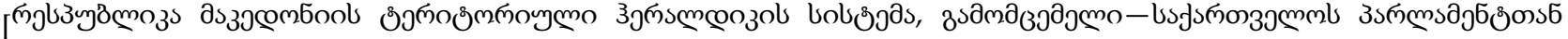

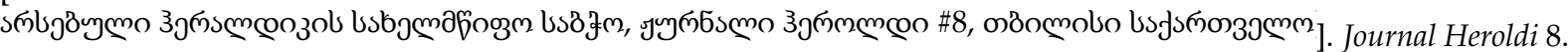

Јоновски, Јован. 2019а. Сонцето и лавот како симболи во хералдиката и вексилологијата на Македонија. Скопје: Македонско грбословно друштво, [Jonovski Jovan, The Sun and the Lion as Symbols in the Heraldry and Vexillology of Macedonia, Skopje: Macedonian Heraldic Soceity].

Јоновски, Јован. 2019b. Развојот на македонската хералдичка мисла. In Историја. Скопје: Здружение на историчарите на Република Македонија, год, LIV, бр. 1, [Jonovski, Jovan. The development of Macedonian heraldic thought, History, Skopje: Society of historians of the Republic of Macedonia].

Jonovski, Jovan. 2020. The Sun and the Lion as Symbols of the Republic of Macedonia: A Heraldic and Vexillological Analysis. Danvers: Flag Heritage Foundation.

Jonovski, Jovan. 2021a. Heraldry in Macedonia with Special Regard to the People's/Socialist Republic of Macedonia until 1991. Genealogy 5: 43. [CrossRef]

Jonovski, Jovan. 2021b. Available online: https:/ /heraldika.org.mk/en/jovan-jonovski/ (accessed on 23 August 2021).

Кузман, Паско, Елизабета Димитрова, аnd Јован Доневред. 2013. Македонија, милениумски културно историски өакти. Скопје: Медиа ПринтМакедонија, УниверзитетСкопје “Евро-Балкан”, Том2, [Kuzman, Pasko, Elizabeta Dimitrova, and Jovan Donev. Macedonia, mileniia old cultural facts. Skopje: Media Print Makedonija, University "Evro-Balkan" Skopje].

Матковски, Александар. 1990. Грбовите на Македонија-прилог кон македонската хералдика. Скопје: Mисла, [Matkovski, Aleksandar, The Coat of Arms of Macedonia-Addition to Macedonian Heraldry, Skopje; Misla].

Nacevski, Ivan. 2014. Macedonian municipal heraldry system. Macedonian Herald 8.

Nacevski, Ivan. 2015. The ratio between the lion gules and the lion or in the work, "The Arms of Macedonia" by Academician Aleksndar Matkovski. Macedonian Herald 9.

Nacevski, Ivan. 2016. The Blazon of the Lion in the Attributed Arms of Alexander III of Macedon. Macedonian Herald 10.

Nacevski, Ivan. 2021. Available online: https://heraldika.org.mk/en/ivan-nacevski/ (accessed on 23 August 2021).

Neubecker, Ottfried. 1997. A Guide to Heraldry. New York: Barns \& Nobles.

Одлука за начинот и постапката на утврдување на грб и знаме на Општина Карпош. 2005, Гласник на Општина Карпош, број 6. June 20, [Decission on the procedures on obtaining coat of arms and flag of Municipality of Karposh, Official Gazzete of the Municipality of Karposh].

Filipova, Snezhana. 2005. Notes on Mijacs' flag. Macedonian Herald 1.

Filipova, Snezhana. 2007. Notes on Mijacs' flag-Reading of applied motiffs. Macedonian Herald 2.

Филипова, Снежана. 2015. Студии за македонската хералдика. Скопје: Мацедоника литера, [Filipova Snezhana, Studies on Macedonian Heraldry, Skopje: Macedonika Litera].

Петровски, Бобан. 2009. Хералдика и инсигни. Скопје: де Гама, [Petrovski, Boban. Heraldry and Insignia, Skopje: de Gama] .

Правилник за употреб $а$ на грб и знаме на општина. 2013. Скопје: Македонско грбословно друштво, [Roolbook for the usage of the coat of arms and the flag of Municipality, Skopje: Macedonain Heraldic Society]. 